\title{
Reviews and syntheses: Hidden forests, the role of vegetated coastal habitats in the ocean carbon budget
}

\author{
Carlos M. Duarte ${ }^{1, *}$ \\ ${ }^{1}$ King Abdullah University of Science and Technology (KAUST), Red Sea Research Center (RSRC), \\ Thuwal, 23955-6900, Saudi Arabia \\ * Invited contribution by Carlos M. Duarte, recipient of the EGU Vladimir Ivanovich Vernadsky Medal 2016. \\ Correspondence to: Carlos M. Duarte (carlos.duarte@kaust.edu.sa)
}

Received: 15 August 2016 - Published in Biogeosciences Discuss.: 24 August 2016

Revised: 21 December 2016 - Accepted: 27 December 2016 - Published: 23 January 2017

\begin{abstract}
Vegetated coastal habitats, including seagrass and macroalgal beds, mangrove forests and salt marshes, form highly productive ecosystems, but their contribution to the global carbon budget remains overlooked, and these forests remain "hidden" in representations of the global carbon budget. Despite being confined to a narrow belt around the shoreline of the world's oceans, where they cover less than 7 million $\mathrm{km}^{2}$, vegetated coastal habitats support about 1 to $10 \%$ of the global marine net primary production and generate a large organic carbon surplus of about $40 \%$ of their net primary production (NPP), which is either buried in sediments within these habitats or exported away. Large, 10-fold uncertainties in the area covered by vegetated coastal habitats, along with variability about carbon flux estimates, result in a 10-fold bracket around the estimates of their contribution to organic carbon sequestration in sediments and the deep sea from 73 to $866 \mathrm{Tg} \mathrm{C} \mathrm{yr}^{-1}$, representing between $3 \%$ and $1 / 3$ of oceanic $\mathrm{CO}_{2}$ uptake. Up to $1 / 2$ of this carbon sequestration occurs in sink reservoirs (sediments or the deep sea) beyond these habitats. The organic carbon exported that does not reach depositional sites subsidizes the metabolism of heterotrophic organisms. In addition to a significant contribution to organic carbon production and sequestration, vegetated coastal habitats contribute as much to carbonate accumulation as coral reefs do. While globally relevant, the magnitude of global carbon fluxes supported by salt-marsh, mangrove, seagrass and macroalgal habitats is declining due to rapid habitat loss, contributing to loss of $\mathrm{CO}_{2}$ sequestration, storage capacity and carbon subsidies. Incorporating the carbon fluxes' vegetated coastal habitats' support into depictions of the carbon budget of the global ocean and its perturbations
\end{abstract}

will improve current representations of the carbon budget of the global ocean.

\section{Introduction}

Accounts of the role of primary producers in the global oceanic carbon cycle traditionally focus on the role of planktonic photosynthetic organisms and ignore, altogether, the potential contribution of marine vegetated coastal habitats (e.g. Falkowski et al., 2000; Fig. 6.1 in Ciais et al., 2013). The tenacity in ignoring the contribution of marine macrophytes is surprising, as not only was a significant role for marine macrophytes in the global oceanic carbon cycle highlighted already in 1981 (Smith, 1981), but estimates of their important role as globally significant carbon sinks developed a decade ago (Duarte et al., 2005) led to the development of a promising new strategy for climate change mitigation (Nature Editorial, 2016), termed Blue Carbon, based on the conservation and restoration of these habitats (Nelleman et al., 2009; McLeod et al., 2011; Duarte et al., 2013a). Moreover, the focus on Blue Carbon has also driven attention to other aspects of the contribution of marine vegetated coastal habitats to the oceanic carbon budget beyond carbon burial in sediments, including export of organic carbon from the coastal to the open ocean (Dittmar et al., 2006; Barrón and Duarte, 2015; Barrón et al., 2014; Krause-Jensen and Duarte, 2016).

Current neglect of the role of marine vegetated coastal habitats in the global carbon budget is largely derived from the flawed rationale that since these habitats are restricted to a 
narrow belt around the shorelines, they cannot possibly have a significant global role when compared to the vast spans of open oceanic waters dominated by phytoplankton, where benthic macrophytes cannot thrive. In addition, incorporating marine vegetated coastal habitats into the global carbon budget is made complicated by difficulties in assigning specific sources to the organic carbon burial in their soils, which is often partially allochthonous (e.g. Kennedy et al., 2010). Further, marine vegetated coastal habitats lack the charisma of other coastal ecosystems, such as coral reefs, and have not received much interest by the general public nor, possibly as a consequence, much research funding to assess their global role (Duarte et al., 2008), a tendency that the current focus on Blue Carbon is helping to revert. Whereas the focus on Blue Carbon has provided a major impetus to assess the global relevance of marine vegetated coastal habitats in the global carbon budget, these efforts have only addressed the contributions of these habitats to organic carbon burial in sediments, and have not addressed other significant contributions of these habitats to the carbon budget of the global ocean. Hence, vegetated coastal habitats represent hidden forests, as they form ecosystems supporting some of the tallest plants in the biosphere (e.g. up to $45 \mathrm{~m}$ long kelps) with similar functions in carbon cycling as forests have, but that are not yet being recognized, despite abundant supporting evidence, as relevant components of the global carbon cycle.

Here I provide an overview of the extent, biomass and production of vegetated coastal habitats and the evidence for their role in the global carbon cycle and discuss how integrating their role in the context of the global ocean leads one to reconsider some of the elements of the status quo of the global ocean carbon budget (e.g. as represented in Fig. 6.1 in Ciais et al., 2013). I then discuss how changes to marine vegetated coastal habitats derived from local impacts and direct human intervention but also from the consequences of climate change would affect the contribution of vegetated coastal habitats to carbon budgets regionally and globally, and identify future research challenges.

\section{Global extent and production of vegetated coastal habitats}

Vegetated coastal habitats occur along the coasts of all continents, but their nature varies depending on latitude and substrate characteristics. Where the substrate consists of soft sediments, muddy or sandy, salt marshes and mangroves typically occupy the intertidal zone, with mangroves dominating in the tropics and salt marshes in the temperate zone, while seagrass occupies the subtidal and sometimes the lower intertidal zone, down to the depth receiving about $1 \%$ of the light incident in the surface (Duarte, 1991; Duarte et al., 2007). Green algae may grow within seagrass meadows, with calcifying algae (e.g. Udotea sp., Padina sp., Halimeda sp.) and Caulerpales dominating in the tropics and subtropics, and
Ulvales in the temperate zone. Macroalgae dominate rocky shores, from the intertidal zone down to depths receiving about 0.01 to $0.5 \%$ of the light incident in the surface, depending on growth form (Gattuso et al., 2006). Macroalgal habitats are typically dominated by brown algae, including kelp communities in temperate, subpolar and polar latitudes, by Sargassum and Turbinaria in the subtropical and tropical zone, and by Cystoseira in warmer temperate waters. Intertidal communities are dominated by Fucus and Ascophyllum from temperate to Arctic latitudes. Foliose and filamentous macroalgae often develop high biomasses in nutrient-rich, estuarine environments (Valiela, 2015), developing massive blooms, known as green tides, in hypereutrophic Chinese coastal areas (e.g. Ye et al., 2011). Mangroves develop forests that range from dwarf, $2 \mathrm{~m}$ tall trees at the poleward edge of their distributional limits and in arid and karstic areas lacking riverine inputs, to very large trees, exceeding $30 \mathrm{~m}$ in height in the wet tropics (Quisthoudt et al., 2012). Kelps also develop submarine forests with fronds of up to $45 \mathrm{~m}$ long, while the landscapes formed by salt marshes and seagrasses correspond more to those characteristic of dense wet meadows on land, with the leaf area index exceeding $8 \mathrm{~m}^{2}$ of leaf per $\mathrm{m}^{2}$ of seafloor covered (Bay, 1984).

The global area occupied by coastal vegetated habitats can be estimated using top-down or bottom-up approaches. The former constrain the global extent by imposing ceilings derived from limiting factors, such as light or substrate availability. Bottom-up approaches attempt to derive a canonical estimate of their global areal extent by adding up the documented area covered in different regions. Unfortunately, such canonical estimates are precluded, for most coastal vegetated habitats, by the fact that only a fraction of them have been mapped. Mangrove forests are the only habitat for which a bottom-up estimate of global extent that is accurate and resolved at the regional level is available. A quasi-canonical estimate of the global area occupied by mangroves (in year 2000) of $0.137 \times 10^{6} \mathrm{~km}^{2}$ was produced based on a detailed inspection of remote sensing images (Giri et al., 2011). Surprisingly, there is no validated estimate, to the best of my knowledge, for the global area of salt marshes, despite the fact that these can also be extracted from remote sensing products. The only estimate available derived, 4 decades ago, assesses the global area of salt marshes at $0.38 \times 10^{6} \mathrm{~km}^{2}$ (Table 1 ), with an uncertainty of about $50 \%$ (Woodwell et al., 1973). However, the saltmarsh area has only been documented for Canada, Europe, the USA and South Africa, adding only $0.022 \times 10^{6} \mathrm{~km}^{2}$ (Chmura et al., 2003), representing $<10 \%$ of the global area estimate, whose accuracy remains highly uncertain. Likewise, there is a large uncertainty as to the area occupied by seagrass and macroalgae, with estimates ranging between $2 \times 10^{6} \mathrm{~km}^{2}$ and $6.8 \times 10^{6} \mathrm{~km}^{2}$ (Table 1). The minimum area of seagrass, based on the total documented area, is much lower, at $0.15 \times 10^{6} \mathrm{~km}^{2}$ (Green and Short, 2003), with an estimate of the likely global seagrass extent of $600000 \mathrm{~km}^{2}$, 
Table 1. Estimates of the global area covered by vegetated coastal habitats, indicating the level of confidence in the estimates and whether they represent lower or upper limit estimates.

\begin{tabular}{lrllr}
\hline Habitat & $\begin{array}{r}\text { Area } \\
\left(10^{6} \mathrm{~km}^{2}\right)\end{array}$ & Reference & Confidence & Notes \\
\hline Mangroves & 0.137 & Giri et al. (2011) & High & 1 \\
Salt marshes & 0.02 & Chmura et al. (2003) & Lower limit & 2 \\
& 0.38 & Woodwell et al. (1973) & Low & 3 \\
Seagrass & 0.15 & Green and Short (2003) & Lower limit & 4 \\
& 0.35 & Duarte et al. (2005) & Low & 5 \\
& 0.6 & Duarte and Chiscano (1999) & Upper limit & 6 \\
& 4.32 & Gattuso et al. (2006) & Upper limit & 7 \\
Macroalgae & 1.4 & Duarte et al. (2013a) & Low & 8 \\
& 2 & Gattuso et al. (1998) & Upper limit & 9 \\
& 3.4 & Charpy-Roubad and Sournia (1990) & Low & 10 \\
& 5.71 & Gattuso et al. (2006) & Upper limit & 11 \\
& 6.8 & Charpy-Roubad and Sournia (1990) & Upper limit & 12 \\
\hline
\end{tabular}

1 Global assessment of Landsat satellite images for year 2000. 2 Based on documented area in Canada, Europe, the USA, and South Africa. 3 Estimated based on the fraction of coastline occupied by estuaries and assuming $20 \%$ of the area of estuaries to be salt marsh. 4 Derived by combining the seagrass area documented regionally. 5 Assumes that about half of the potential area has been lost. 6 Assumed documented area to be $1 / 4$ of total area. 7 Gattuso et al. (2006) combined estimates of underwater light penetration, global bathymetry and the light requirements of seagrass to estimate the potential area available for seagrass. 8 Substracts the likely seagrass area from Duarte and Chiscano (1999) from the total macrophyte area in Gattuso et al. (1998). 9 Area of estuaries, algal beds and reefs from Table 1 in Whitaker and Likens (1973) used by Gattuso et al. (1998) to represent global macrophyte (seagrass + macroalgae) area. 10 Charpy-Roubad and Sournia (1990) consider that only half of the potential area $\left(6.8 \times 10^{6} \mathrm{~km}^{2}\right)$ is occupied. 11 Gattuso et al. (2006) combined estimates of underwater light penetration, global bathymetry and the light requirements of macroalgae to estimate the potential area available for macroalgae. 12 Estimated as the potential area available for macroalgae based on a literature review.

which assumes that only $1 / 4$ of the extant global seagrass area has been documented (Duarte and Chiscano, 1999, Table 1). Gattuso et al. (2006) calculated the potential coastal area marine macrophytes may occupy on the basis of the assessment of light requirements for marine macrophytes and light penetration around the coastal ocean. This procedure resulted in an estimate of the coastal area receiving sufficient solar irradiance at the seafloor to support seagrasses of $5.19 \times 10^{6} \mathrm{~km}^{2}$ (Gattuso et al., 2006). This surface area is 35 times larger than the documented seagrass extension of $0.15 \times 10^{6} \mathrm{~km}^{2}$ (Green and Short, 2003) and about 9 times larger than the estimated likely area covered by seagrasses, estimated at $0.6 \times 10^{6} \mathrm{~km}^{2}$ (Table 1). Gattuso et al. (2006) also calculated the potential global extent of macroalgal habitats at $5.71 \times 10^{6} \mathrm{~km}^{2}$ in the non-polar and Arctic regions, respectively. This is about $1 \times 10^{6} \mathrm{~km}^{2}$ below the maximum area estimated by Charpy-Roubad and Sournia (1990), although this difference may be accounted for in the area covered in polar regions, which may be substantial (KrauseJensen and Duarte, 2014). The Gattuso et al. (2006) estimate of the potential area covered by macroalgae exceeds their estimates of that occupied by seagrass, a consequence of the lower minimum light requirements of macroalgae compared to seagrass, which have to support considerable nonphotosynthetic (root and rhizome) biomass (Duarte et al., 1998).

The great uncertainty in the area occupied by marine vegetated coastal habitats is compounded by the fact that this is a dynamic property, as vegetated coastal habitats are experiencing significant losses derived from anthropogenic impacts (Duarte et al., 2013a). The area occupied by seagrass, mangroves and salt marshes has declined greatly due to human occupation of the coastal zone, land reclamation, deforestation and eutrophication, resulting in global loss rates of about $1 \% \mathrm{yr}^{-1}$ for angiosperm-dominated ecosystems $(0.7$ to $3 \% \mathrm{yr}^{-1}$, depending on ecosystems, Duarte et al., 2008, 2013a), twice as high as those reported for tropical forests (Duarte et al., 2008). For instance, whereas the area occupied by seagrass is likely to be 4 times larger than that mapped to date, consideration of seagrass losses during the 20th century (Waycott et al., 2009) suggests that the more likely global area occupied by seagrass is now only $0.35 \times 10^{6} \mathrm{~km}^{2}$ (Table 1).

Early estimates of the global net primary production (NPP) of marine macrophytes assessed this to be at least $1 \mathrm{Pg} \mathrm{C} \mathrm{yr}^{-1}$ (Whitaker and Likens, 1973; de Vooys, 1979; Smith, 1981), within the broad range of current estimates of the net community production, NCP, of marine macrophytes $(0.18$ to $4.84 \mathrm{Pg} \mathrm{Cyr}^{-1}$, Table 2), although the most likely value is 1.9 $\mathrm{Pg} \mathrm{C} \mathrm{yr}^{-1}$, dominated by macroalgae (Table 2). Recently, Krause-Jensen and Duarte (2016) propagated uncertainties in the areal extent and primary production of macroalgae to derive an estimate of NPP for macroalgae at $1.52 \mathrm{Pg} \mathrm{C} \mathrm{yr}^{-1}$, with the 25 th and 75 th percentiles of this estimate at 1.02 and $1.96 \mathrm{Pg} \mathrm{Cyr}^{-1}$. However, a similar exercise has not yet been attempted for other vegetated habitat types. Hence, the 
Table 2. Net primary production (NPP), carbon burial and export production of vegetated coastal habitats. Lower range of areal production values from Duarte and Chiscano (1999) and upper range of areal seagrass production calculated from gross community production in Gatuso et al. (1998), assuming community respiration $(R) R=0.5$ GPP from Duarte and Cebrián (1996). Upper value for areal mangrove and saltmarsh production calculated as the ratio between global NPP and global area in Duarte and Cebrián (1996). Range of global macroalgal production from Krause-Jensen and Duarte (2016). Percent NPP buried and exported for various habitats from Duarte and Cebrian (1996), and global burial and export ranges calculated by combining these percent values with the range of global NPP values.

\begin{tabular}{|c|c|c|c|c|c|c|}
\hline \multirow[t]{2}{*}{ Habitat } & \multicolumn{2}{|c|}{ NPP } & \multicolumn{2}{|r|}{ Burial } & \multicolumn{2}{|r|}{ Export } \\
\hline & $\mathrm{g} \mathrm{C} \mathrm{m}^{-2} \mathrm{yr}^{-1}$ & Range $\left(\mathrm{PgC}_{\mathrm{yr}}{ }^{-1}\right)$ & $\%$ NPP & Range ( $\left.\mathrm{Pg} \mathrm{C} \mathrm{yr}^{-1}\right)$ & $\%$ NPP & Range $\left(\mathrm{PgC}_{\mathrm{yr}}-1\right)$ \\
\hline Seagrass & $394-449$ & $0.06-1.94$ & 15.9 & $0.01-0.308$ & 24.3 & $0.014-0.471$ \\
\hline Macroalgae & $91-522$ & $0.127-2.9$ & 0.4 & $0.0005-0.012$ & 43.5 & $0.055-1.26$ \\
\hline Salt marsh & $438-1100$ & $0.17-0.42$ & 16.7 & $0.028-0.070$ & 18.6 & $0.031-0.078$ \\
\hline Mangroves & 394-1000 & $0.05-0.15$ & 10.4 & $0.005-0.016$ & 29.5 & $0.014-0.044$ \\
\hline Total & & $0.407-5.41$ & & $0.044-0.404$ & & $0.116-1.85$ \\
\hline
\end{tabular}

total net community production of marine vegetated habitats spans a broad 10-fold range from a minimum of 0.4 to $5.4 \mathrm{Pg} \mathrm{Cyr}^{-1}$ (Table 2), due to combinations of uncertainties in the areal extent, the dominant source of uncertainty, and the average net primary production per unit area. Their net primary production, however, represents between $<1$ and about $10 \%$ of marine net primary production globally (Duarte and Cebrián, 1996).

\section{The fate of the production of vegetated coastal habitats}

The role of vegetated coastal habitats in the global carbon budget is not, however, reflected in their NPP, as the fraction of NPP that is recycled within the ecosystem, through consumption, decomposition and, ultimately, respiratory processes, supports no net carbon flux. Hence, the focus should not be on the NPP supported by vegetated coastal habitats, but on its fate (Duarte and Cebrián, 1996). The net primary production of vegetated coastal habitats meets four possible fates: it may be (1) consumed by herbivores and detritivores, helping support the biomass and production of coastal food webs, (2) remineralized through respiration or decomposition by microorganisms and metazoans, (3) buried in sediments, or (4) exported away from the vegetated coastal habitat (Duarte and Cebrián, 1996). Based on available estimates, Duarte and Cebrián (1996) concluded that marine macrophytes export or bury about $40 \%$, of their NPP, on average, ranging from average values of $35.3 \%$ for marsh plants to $43.9 \%$ for macroalgae (Table 2).

Vegetated coastal habitats are, therefore, strongly autotrophic ecosystems, as they produce organic carbon far in excess of local requirements (Duarte and Cebrián, 1996; Duarte et al., 2010; Table 2). Thus, they act as strong sinks for atmospheric $\mathrm{CO}_{2}$, as reflected in $p \mathrm{CO}_{2}$ values typically sub-saturated relative to atmospheric equilibrium above submerged canopies (Smith, 1981; Gazeau et al., 2005), driving a net uptake of atmospheric $\mathrm{CO}_{2}$. In contrast, other coastal marine habitats, such as coral reefs (Gattuso et al., 1998) and estuarine environments, typically act as sources of $\mathrm{CO}_{2}$ into the atmosphere (Gattuso et al., 1998; Frakignoulle et al., 1998; Borges, 2005).

A fraction of the excess carbon produced by vegetated coastal habitats accumulates in their sediments. Indeed, salt marshes, mangroves and seagrass meadows have been shown to support organic carbon stocks (Donato et al., 2011; Fourqurean et al., 2012) and burial rates (Duarte et al., 2005, 2013a; McLeod et al., 2011) in the underlying sediments comparable to or exceeding those supported by forests on land (Table 2). As a consequence, angiosperm-dominated coastal ecosystems have been estimated to be responsible for $50 \%$ of the organic carbon burial, estimated at about 110 to $130 \mathrm{Tg} \mathrm{Cyr}^{-1}$, in marine sediments, despite occupying only $0.2 \%$ of the ocean area (Duarte et al., 2005). This estimate needs be increased with a small contribution of about 6 to $10 \mathrm{Tg} \mathrm{Cyr}^{-1}$ of carbon from macroalgae growing in soft sediments (Duarte and Cebrián, 1996; Krause-Jensen and Duarte, 2016). The estimate of the global burial of organic carbon in vegetated coastal habitats involves considerable uncertainties, compounding the large uncertainties in their global extent and NPP, discussed above, so the estimates range 10-fold, from 0.044 to $0.404 \mathrm{Pg} \mathrm{C} \mathrm{yr}^{-1}$ (Table 2).

Vegetated coastal habitats export, as terrestrial forests do, a significant fraction of their production. Organic carbon burial represents a modest, about $18 \%$, fraction of the net community production $(\mathrm{NCP}=$ burial + export in Table 2$)$ of vegetated coastal habitats, dominated (55\% of total NCP) by export of marine macroalgae (Table 2). Hence, most (about $82 \%$ ) of the NCP of vegetated coastal habitats is exported, either as particulate or dissolved organic carbon (POC and DOC, respectively). Tracking the fate of the export production of vegetated coastal habitats is, however, far more challenging than evaluating the carbon buried within their sediments. Carbon of coastal macrophytes can be tracked using a combination of stable isotope signatures, for seagrass and macroalgae, which are typically enriched in ${ }^{13} \mathrm{C}$ rel- 
ative to other primary producers (Hemminga and Mateo, 1996), specific organic markers, such as lipids, sterols and carotenoids, used mostly for macroalgae (Hardison et al., 2013; Chikaraishi, 2014), and, in principle, DNA barcoding approaches (Lucas et al., 2012; Nguyen et al., 2015), which may provide an unprecedented taxonomic resolution on the source of organic carbon, although these have not been tested to this end as yet.

A variable fraction of the exported material is deposited in the shores as beach-cast litter, with an important role in supporting terrestrial coastal food webs (Ochieng and Erftemeijer, 1999; Ince et al., 2007; Mellbrand et al., 2011) and shoreline protection (Simeone and De Falco, 2012; Boudouresque et al., 2015). Beach-cast deposits can reach phenomenal biomasses (Barreiro et al., 2011), such as up to $500 \mathrm{~kg}$ of dry wt $\mathrm{m}^{-1}$ of the shoreline of Posidonia oceanica litter washed on the shores of Tabarca, Spain (Mateo et al., 2003). Beachcast material supports high metabolic rates (Coupland et al., 2007) and represents a significant subsidy to terrestrial food webs (e.g. Ochieng and Erftemeijer, 1999; Ince et al., 2007; Mellbrand et al., 2011), particularly on arid shores (e.g. Pollis and Hurd, 1996), but the paucity of estimates on fluxes precluded any assessment of the fraction of export material that ends up washed on shores globally. A study in a Kenyan lagoon estimated that $19 \%$ of seagrass NPP were supplied as beach-cast litter (Ochieng and Erftemeijer, 1999). In addition, some of the beach-cast material is entrained again in the sea during storms or extreme tides, so it may be only temporarily deposited on shore.

Much of the carbon exported from vegetated coastal habitats is released as dissolved organic carbon (DOC). Dittmar et al. (2006) reported a large export of DOC from Brazilian mangroves, and calculated that DOC export from mangrove ecosystems represents approximately $26.4 \mathrm{Tg} \mathrm{C} \mathrm{yr}^{-1}$, accounting for $60 \%$ of the upper estimate of mangrove $\mathrm{C}$ export (Table 2), consistent with estimates by Bouillon et al. (2008). Barrón et al. (2014) compiled estimates of net DOC release by seagrasses to conclude that they release, on

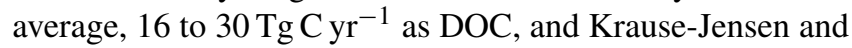
Duarte (2016) estimated the DOC released by macroalgae at 355 (range 194 to 486 ) $\mathrm{Tg} \mathrm{C} \mathrm{yr}^{-1}$. Unfortunately, there is no estimate of the DOC export by salt marshes, but that released by mangroves, seagrass and macroalgae together accounts for about $30 \%$ of their total export flux (Table 2). Much of this DOC export may be remineralized by bacteria, as DOC exported from the coastal ocean has been argued to subsidize excess respiration in oligotrophic, open ocean communities (Barrón et al., 2015). Krause-Jensen and Duarte (2016) estimated that $1 / 3$ of the DOC flux is exported, by vertical turbulent diffusive transport, below the mixed layer, eventually reaching the deep sea $(>1000 \mathrm{~m})$, where some of it would be sequestered, as organic carbon entering the deep sea is removed from exchange from the atmosphere over centennial timescales, thereby qualifying as sequestration independently of whether it is remineralized or not.
The bulk (about $70 \%$ ) of carbon export from vegetated carbon export is released as particulate organic carbon (POC). Some of the POC export is sequestered in depositional sites outside the vegetated coastal habitats, including sediments in the continental shelf or the deep ocean. KrauseJensen and Duarte (2016) reviewed available evidence of the presence of macroalgal carbon in shelf sediments and the deep sea to conclude that a total of about 14 and $35 \mathrm{Tg} \mathrm{C} \mathrm{yr}^{-1}$ of macroalgal POC is sequestered in continental shelf sediments outside macroalgal beds and the deep sea, respectively. Hence, burial of macroalgal carbon beyond macroalgal habitats is at least 4 times greater than burial in macroalgal beds occurring in soft sediments. Reports of seagrass carbon in unvegetated sediments adjacent to seagrass meadows (e.g. Kennedy et al., 2010) and leaf litter on deep-sea sediments (e.g. Moore, 1963; Wolff, 1976) suggests that, as for macroalgae, seagrass carbon also reaches depositional sites outside seagrass meadows. Duarte and Krause-Jensen (2017) synthesized available evidence to estimate that about $24 \mathrm{TgC}^{-1}$ of seagrass carbon is sequestered beyond the meadow.

Krause-Jensen and Duarte (2016) and Duarte and KrauseJensen (2017) estimated that $1 / 4$ of the export flux of macroalgae and seagrasses is sequestered in unvegetated sediments or the deep sea. Assuming that the export flux of mangroves and salt marshes meets a similar fate, would suggest that vegetated coastal habitats contribute to sequestration of about 29 to $462 \mathrm{Tg} \mathrm{Cyr}^{-1}$ beyond their habitats. Macroalgae, which had been largely neglected as components of marine carbon sequestration (Hill et al., 2015, Krause-Jensen and Duarte, 2016), now emerge as main contributors to the role of vegetated coastal habitats in carbon sequestration (Krause-Jensen and Duarte, 2016). Combining burial in blue carbon habitats with sequestration beyond them indicates that vegetated coastal habitats sequester 73 to $866 \mathrm{Tg} \mathrm{C} \mathrm{yr}^{-1}$. Hence, vegetated coastal habitats would contribute between a minimum of $0.3 \%$ to a maximum of $1 / 3$ of the biological $\mathrm{CO}_{2}$ removal by marine biota estimated to represent about $2000 \mathrm{Tg} \mathrm{C} \mathrm{yr}^{-1}$, which had hitherto been attributed entirely to phytoplankton photosynthesis in depictions of the global carbon budget (Fig. 6.4 in Ciais et al., 2013). Moreover, the carbon exported to the open ocean contributes to subsidizing heterotrophic metabolism in open ocean communities, contributing to supporting the excess community respiration over production often encountered in the oligotrophic ocean (Duarte et al., 2013b; Barrón and Duarte, 2015).

The estimates above all refer to organic carbon, the component of the ocean carbon budget that has been the focus of carbon assessments in the framework of climate change (Ciais et al., 2013). However, vegetated coastal habitats are also important sites for carbonate formation and dissolution, although information on the global fluxes they support has received even less attention than that of organic carbon fluxes. Calcareous algae, such as coralline and Halimeda, have been long recognized to be important contributors to carbonate 
formation, with estimates of net calcification by calcifying algae being on the order of $20 \mathrm{Tg} \mathrm{C} \mathrm{yr}^{-1}$ for Halimeda bioherms (Milliman and Droxler, 1996). The carbonate production in seagrass meadows was recently estimated at 20 to $75 \mathrm{Tg} \mathrm{C} \mathrm{yr}^{-1}$ (Mazarrasa et al., 2015). There is no information on the carbonate deposition in mangrove or salt-marsh sediments, probably due to the belief that they are unlikely to accumulate carbonate. However, mangroves have also been reported to develop carbonate soils (e.g. Koch and Snedaker, 1997), so even if small there must be some contribution from mangroves, and, likely, salt marshes. Hence, carbonate accumulation in vegetated coastal sediments is likely to be, at least, comparable to that of coral reefs ( $>40$ to $95 \mathrm{Tg} \mathrm{C} \mathrm{yr}^{-1}$ in vegetated coastal sediments vs. $84 \mathrm{Tg} \mathrm{C} \mathrm{yr}^{-1}$ for coral reefs, Milliman and Droxler, 1996).

As carbonate production in shallow waters results in the release of $0.63 \mathrm{~mol}$ of $\mathrm{CO}_{2}$ per mol of $\mathrm{CaCO}_{3}$ precipitated (Smith, 2013), the accumulation of $\mathrm{CaCO}_{3}$ in vegetated coastal sediments could be considered to offset carbon sequestration by 25 to $60 \mathrm{TgC}^{-1}$, thereby reducing organic carbon sequestration in vegetated coastal habitats. However, this simple interpretation considers carbonate and organic burial to be independent, which may be incorrect. In particular, organic matter tends to be closely associated with $\mathrm{CaCO}_{3}$ particles, becoming less accessible to remineralization by microorganisms, resulting in significantly greater $\mathrm{C}_{\text {org }}$ preservation in carbonate-rich sediments (Mayer, 1994). Moreover, remineralization of sediment organic matter increases $\mathrm{CO}_{2}$ and may lead to carbonate dissolution, which would in turn lead to $\mathrm{CO}_{2}$ removal (Smith, 1981), so co-deposition of organic and inorganic carbon may buffer against $\mathrm{CO}_{2}$ release of disturbed sedimentary deposits. Overall, our understanding of the carbonate budget of vegetated coastal habitats lags well behind that of organic carbon, with which it likely interacts rather than being just a parallel, independent process.

\section{Future trends and research needs}

Resolving the uncertainties in the global area covered by saltmarsh, seagrass and macroalgal habitats and its regional distribution is an imperative, as these uncertainties remain the largest source of uncertainty as to their role in the global carbon cycle. The rise of interest in Blue Carbon strategies has led to an increase in the data available on organic carbon stocks and burial rates in vegetated coastal habitats, including efforts to improve the representation of vegetated coastal habitats outside North America, Europe and Australia, where the majority of the estimates come from. However, the fate of the large export flux remains unaccounted for, with a first-order assessment available only for macroalgal and seagrass carbon (Krause-Jensen and Duarte, 2016; Duarte and Krause-Jensen, 2017), which are, however, responsible for the largest export flux.
The large uncertainties as to the global extent of vegetated coastal habitats are compounded by its rapid change, as these habitats experience some of the steepest rates of any ecosystem, at loss rates of 0.7 to $3 \% \mathrm{yr}^{-1}$, depending on ecosystems (Duarte et al., 2008, 2013a; Waycott et al., 2009), 2 to 10 times greater than that of tropical forests. These losses are largely attributable to local anthropogenic perturbations, such as mechanical destruction in converting them into aquaculture ponds, urban areas and other uses, eutrophication and other perturbations (Duarte, 2002; Waycott et al., 2009). However, climate change plays an increasingly larger role, leading to shifting biogeographical ranges, generally involving losses in the equator-ward ranges (e.g. Wernberg et al., 2010; Moy and Christie, 2012; Tanaka et al., 2012; Voemann et al., 2013) and poleward migration at the poleward edge, which for macroalgae occurs at characteristic rates of about $30 \mathrm{~km} \mathrm{decade}{ }^{-1}$ (Poloczanska et al., 2014). The prospect for poleward kelp expansions is particularly significant for the Arctic, whose convoluted coastline would offer a large habitat for kelps in a rapidly warming Arctic (Krause-Jensen and Duarte, 2014). In addition, macroalgal aquaculture has emerged as a globally significant activity, with a yield of 26.9 million ton (dry weight) in 2013, and growing at a rate of $7.9 \pm 0.2 \% \mathrm{yr}^{-1}$ (data from www.fao.org/figis). This represents a production of about $10 \mathrm{Tg} \mathrm{Cyr}^{-1}$, about $5 \%$ of global seaweed production (Table 2). Whereas POC export from macroalgal farms will likely be greatly reduced compared to wild stocks as macroalgae are harvested, macroalgal crops should export comparable DOC to wild stocks, along with some POC, thereby likely contributing to enhancing the role of macroalgae in carbon export and sequestration.

The large changes in the area covered by vegetated coastal habitats, with at least $1 / 3$ of the global cover already lost, together with their significant contribution to carbon cycling, indicate that perturbations to vegetated coastal habitats should contribute to the components of greenhouse emissions termed "land-use change" sources, although this has not been accounted for. A third of the loss in the global biomass of marine macrophytes of about $1 \mathrm{PgC}$ (Smith, 1981), one of the components of vegetated coastal habitats, would have contributed about $0.33 \mathrm{Pg} \mathrm{C}$ to accumulated emissions. However, the emissions derived from the erosion of the large carbon stocks under disturbed vegetated coastal habitats are potentially much greater, at about $0.12 \mathrm{Pg} \mathrm{C} \mathrm{yr}^{-1}$ (Pendelton et al., 2012). Assessments of the realized cumulative greenhouse gas emissions due to disturbance of vegetated coastal habitats and the risks of further emissions from future disturbance should be incorporated into accounts of realized perturbations to the global carbon budget and scenarios of possible future perturbations. Moreover, these assessments, still pending, are essential to evaluate the potential global benefits of restoration and conservation measures to recover and avoid the loss of these intense carbon sinks. Lastly, evidence of the major export of organic carbon from vegetated coastal habitats to the open ocean should prompt 
research, assisted by the availability of more and more powerful markers, to elucidate its role in the functioning of the open ocean and deep-sea ecosystems, a role that was already considered significant 50 years ago (cf. Krause-Jensen and Duarte, 2016).

Whereas estimates of offshore export of Blue Carbon are now becoming available (Cebrián and Duarte, 1996; Duarte et al., 2005; Dittmar et al., 2006; Barrón et al., 2014; Barrón and Duarte, 2015; Krause-Jensen and Duarte, 2016; Duarte and Krause-Jensen 2017), the exchange of carbon across the air-sea and land-ocean boundaries of vegetated coastal habitats remains poorly resolved. The strong autotrophic nature of macroalgal and seagrass habitats is further reflected in their role as strong sinks for atmospheric $\mathrm{CO}_{2}$ (e.g. Gazeau et al., 2005; Unsworth et al., 2012; Tokoro et al., 2014; Ikawa and Oechel, 2015). Seagrass, salt marshes, macroalgae and mangroves all contribute significant loads of material to adjacent beaches, where they can accumulate large carbon stocks (e.g. Mateo et al., 2003; Simeone and de Falco, 2012; Gomez et al., 2013). However, they receive greater subsidies of plankton and land-derived "green carbon", which have been shown to comprise typically about $50 \%$ of the organic carbon stock in seagrass sediments (Kennedy et al., 2010). Hence, organic carbon input from offshore and land sources contribute to the large carbon burial capacity of vegetated coastal habitats while allowing them to export a significant fraction of their own production. Resolving the exchange of carbon between vegetated coastal habitats and adjacent marine, terrestrial and atmospheric components will help further constrain their local and global role in carbon budgets, as well as the consequences of losses or gains of these habitats for carbon flow.

\section{Conclusions}

Despite current uncertainties it is clear that future representations of the carbon budget of the coastal ocean should cease to ignore vegetated coastal habitats or assume that this component is lumped within the term "marine biota" present in current representations (e.g. Ciais et al., 2013), which is not the case, as the associated fluxes and pools are those corresponding to marine plankton. The important role of vegetated coastal habitats in the carbon budget, contributing 1 to $10 \%$ of oceanic net primary production (Smith, 1981), 0.3 to $1 / 3$ of the oceans' biological pump and $>0.6 \%$ to $2 / 3$ of carbon burial in sediments is now evident to scientists and policy makers and seems to be ignored only by global carbon budget modellers (e.g. Ciais et al., 2013), for whom these habitats continue to be hidden forests.

Some years ago, a working group led by Jon J. Cole, Yves T. Prairie and me synthesized available evidence to point to globally significant organic carbon burial and $\mathrm{CO}_{2}$ emissions from freshwater ecosystems (Cole et al., 2007). This effort led to these fluxes (200 and $1000 \mathrm{Tg} \mathrm{C} \mathrm{yr}^{-1}$, respec- tively) now being explicitly captured in the latest representation of the global carbon budget by the IPCC (Fig. 6.4, Ciais et al., 2013). The carbon fluxes dominated by the "hidden forests" of the coastal ocean are likely to be at least of a similar magnitude and should, therefore, also be captured in future representations of the global carbon budget. This will require an additional effort to improve the precision of current estimates. The uncertainty in the global area these habitats cover has not been narrowed down, for seagrass, macroalgae and salt marshes, for several decades now, and the estimates of the global NPP contributed by these habitats and its fate have not been revisited since the estimates provided by Smith (1981) and Duarte and Cebrián (1996) several decades ago. As in the case of freshwater carbon emissions and burial, incorporating the carbon fluxes' vegetated coastal habitats' support into depictions of the global carbon budget and its perturbations also requires that the research community addressing carbon fluxes in vegetated coastal habitats reach out to establish links to share knowledge on these fluxes with the working groups involved in assessing the global carbon budget.

Competing interests. The authors declare that they have no conflict of interest.

Acknowledgement. This paper conveys my lecture in accepting the Vladimir Ivanovich Vernadsky Medal 2016 of the European Geophysical Union. I thank the colleagues that nominated and supported me for this award and the many colleagues that have collaborated in this research over the years, particularly Dorte Krause-Jensen, Nuria Marbá, Jack Middelburg, Jim Fourqurean, Paul Lavery, Miguel Angel Mateo, Peter Macreadie, Oscar Serrano, Pere Masqué, Inés Mazarrasa and Catherine Lovelock.

Edited by: Jack Middelburg

Reviewed by: two anonymous referees

\section{References}

Barreiro, F., Gómez, M., Lastra, M., López, J., and De la Huz, R.: Annual cycle of wrack supply to sandy beaches: effect of the physical environment, Mar. Ecol.-Progr. Ser., 433, 65-74, 2011.

Barrón, C. and Duarte, C. M.: Dissolved organic carbon pools and export from the coastal ocean, Global Biogeochem. Cy., 29, 1725-1738, 2015.

Barrón, C., Apostolaki, E. T., and Duarte, C. M.: Dissolved organic carbon fluxes by seagrass meadows and macroalgal beds, Front. Mar. Sci., 1, 42, doi:10.3389/fmars.2014.00042, 2014.

Bay, D.: A field study of the growth dynamics and productivity of Posidonia oceanica (L.) Delile in Calvi Bay, Corsica, Aquat. Bot., 20, 43-64, 1984.

Borges, A. V.: Do we have enough pieces of the Jigsaw to integrate $\mathrm{CO}_{2}$ fluxes in the coastal ocean?, Estuaries, 28, 3-27, doi:10.1007/ BF02732750, 2005. 
Boudouresque, C. F., Pergent, G., Pergent-Martini, C., Ruitton, S., Thibaut, T., and Verlaque, M.: The necromass of the Posidonia oceanica seagrass meadow: fate, role, ecosystem services and vulnerability, Hydrobiologia, 1-18, doi:10.1007/s10750015-2333-y, 2015.

Bouillon, S., Borges, A. V., Castañeda-Moya, E., Diele, K., Dittmar, T., Duke, N. C., Kristensen, E., Lee, S. Y., Marchand, C., Middelburg, J. J., Rivera-Monroy, V. H., Smith III, T. J., and Twilley, R. R.: Mangrove production and carbon sinks: A revision of global budget estimates, Global Biogeochem. Cy., 22, GB2013, doi:10.1029/2007GB003052, 2008.

Charpy-Robaud, C and Sournia, A.: The comparative estimation of phytoplanktonic microphytobcnthic production in the oceans, Mar. Microbial, Food Webs, 4, 31-57, 1990.

Chikaraishi, Y.: Treatise on Geochemistry, 5: Organic Geochemistry, edited by: Birrer, B., Falkowski, P., and Freeman, K., Elsevier, 2014.

Chmura, G. L., Anisfeld, S. C., Cahoon, D. R., and Lynch, J. C.: Global carbon sequestration in tidal, saline wetland soils, Global Biogeochem. Cy., 17, 1111, doi:10.1029/2002GB001917, 2003.

Ciais, P., Sabine, C., Bala, G., Bopp, L., Brovkin, V., Canadell, J., Chhabra, A., DeFries, R., Galloway, J., Heimann, M., Jones, C., Le Quere, C., Myneni, R. B., Piao, S., and Thornton, P.: Carbon and Other Biogeochemical Cycles, in: Climate Change 2013: The Physical Science Basis, Contribution of Working Group I to the Fifth Assessment Report of the Intergovernmental Panel on Climate Change, edited by: Stocker, T. F., Qin, D., Plattner, G.K., Tignor, M., Allen, S. K., Boschung, J., Nauels, A., Xia, Y., Bex, V., and Midgley, P. M., Cambridge University Press, Cambridge, United Kingdom and New York, USA, 2013.

Cole, J., Prairie, Y., Caraco, N., McDowell, W., Tranvil, L., Striegl, R., Duarte, C. M., Kortelainen, P., Downing, J., Middleburg, J., and Melack, J.: Plumbing the global carbon cycle: Integrating inland waters into the terrestrial carbon budget, Ecoystems, 10, 171-184, 2007.

Coupland, G. T., Duarte, C. M., and Walker, D. I.: High metabolic rates in beach cast communities, Ecosystems, 10, 1341-1350, 2007.

De Vooys, C. G. N.: The Global Carbon Cycle, edited by: Bolin, B., Degens, E. T., Kempe, S., and Ketner, P., Wiley, New York, 1979.

Dittmar, T., Hertkorn, N., Kattner, G., and Lara, R. J.: Mangroves, a major source of dissolved organic carbon to the oceans, Global Biogeochem. Cy., 20, GB1012, doi:10.1029/2005GB002570, 2006.

Donato, D. C., Kauffman, J. B., Murdiyarso, D., Kurnianto, S., Stidham, M., and Kanninen, M.: Mangroves among the most carbonrich forests in the tropics, Nat. Geosci., 4, 293-297, 2011.

Duarte, C. M.: Seagrass depth limits, Aquat. Bot., 40, 363-377, 1991.

Duarte, C. M.: The future of seagrass meadows, Environ. Conserv., 29, 192-206, 2002.

Duarte, C. M. and Cebrián, J.: The fate of marine autotrophic production, Limnol. Oceanogr., 41, 1758-1766, 1996.

Duarte, C. M. and Chiscano, C. L.: Seagrass biomass and production: A reassessment, Aquat. Bot., 65, 159-174, 1999.

Duarte, C. M. and Krause-Jensen, D.: Export from seagrass meadows contributes to marine carbon sequestration, Front. Mar. Sci., doi:10.3389/fmars.2017.00013, 2017.
Duarte, C. M., Merino, M., Agawin, N. S. R., Uri, J., Fortes, M. D., Gallegos, M. E., Marbá, N., and Hemminga, M.: Root production and belowground seagrass biomass, Mar. Ecol.-Progr. Ser., 171, 97-108, 1998.

Duarte, C. M., Middelburg, J. J., and Caraco, N.: Major role of marine vegetation on the oceanic carbon cycle, Biogeosciences, 2, 1-8, doi:10.5194/bg-2-1-2005, 2005.

Duarte, C. M., Marbà, N., Krause-Jensen, D., and SánchezCamacho, M.: Testing the predictive power of seagrass depth limit models, Estuar. Coast., 30, 652-656, 2007.

Duarte, C. M., Dennison, W. C., Orth, R. J. W., and Carruthers, T. J. B.: The charisma of coastal ecosystems: addressing the imbalance, Estuar. Coast., 31, 233-238, 2008.

Duarte, C. M., Marbà, N., Gacia, E., Fourqurean, J. W., Beggins, J., Barrón, C., and Apostolaki, E. T.: Seagrass community metabolism: Assessing the carbon sink capacity of seagrass meadows, Global Biogeochem. Cy., 24, GB4032, doi:10.1029/2010GB003793, 2010.

Duarte, C. M., Losada, I. J., Hendriks, I. E., Mazarrasa, I., and Marbà, N.: The role of coastal plant communities for climate change mitigation and adaptation, Nature Climate Change, 3, 961-968, 2013a.

Duarte, C. M., Regaudie-de-Gioux, A., Arrieta, J. M, DelgadoHuertas, A., and Agustí, S.: The oligotrophic ocean is heterotrophic, Annu. Rev. Mar. Sci., 5, 551-569, 2013 b.

Falkowski, P., Scholes, R. J., Boyle, E. E. A., Canadell, J., Canfield, D., Elser, J., Gruber, N., Hibbard, K., Högberg, P., Linder, S., and Mackenzie, F. T.: The global carbon cycle: a test of our knowledge of earth as a system, Science, 290, 291-296, 2000.

Frankignoulle, M., Abril, G., Borges, A., Bourge, I., Canon, C., Delille, B., Libert, E., and Thetate, J. P.: Carbon dioxide emission from European estuaries, Science, 282, 434-436, 1998.

Fourqurean, J. W., Duarte, C. M., Kennedy, H., Marbà, N., Holmer, M., Mateo, M. A., Apostolaki, E. T., Kendrick, G. A., KrauseJensen, D., McGlathery, K. J., and Serrano, O.: Seagrass ecosystems as a globally significant carbon stock, Nat. Geosci., 5, 505$509,2012$.

Gattuso, J.-P., Frankignoulle, M., and Wollast, R.: Carbon and carbonate metabolism in coastal aquatic ecosystems, Annu. Rev. Ecol. Syst., 29, 405-434, 1998.

Gattuso, J.-P., Gentili, B., Duarte, C. M., Kleypas, J. A., Middelburg, J. J., and Antoine, D.: Light availability in the coastal ocean: impact on the distribution of benthic photosynthetic organisms and their contribution to primary production, Biogeosciences, 3, 489-513, doi:10.5194/bg-3-489-2006, 2006.

Gazeau, F., Duarte, C. M., Gattuso, J.-P., Barrón, C., Navarro, N., Ruiz, S., Prairie, Y. T., Calleja, M., Delille, B., Frankignoulle, M., and Borges, A. V.: Whole-system metabolism and $\mathrm{CO}_{2}$ fluxes in a Mediterranean Bay dominated by seagrass beds (Palma Bay, NW Mediterranean), Biogeosciences, 2, 43-60, doi:10.5194/bg2-43-2005, 2005.

Giri, C., Ochieng, E., Tieszen, L. L., Zhu, Z., Singh, A., Loveland, T., Masek, J., and Duke, N.: Status and distribution of mangrove forests of the world using earth observation satellite data, Glob. Ecol. Biogeogr., 20, 154-159, 2011.

Gómez, M., Barreiro, F., López, J., Lastra, M., and de la Huz, R.: Deposition patterns of algal wrack species on estuarine beaches, Aquat. Bot., 105, 25-33, 2013. 
Green, E. P. and Short, F. T.: World atlas of seagrasses, Berkeley, CA, California University Press, 2003.

Hardison, A. K., Canuel, E. A., Anderson, I. C., Tobias, C. R., Veuger, B., and Waters, M. N.: Microphytobenthos and benthic macroalgae determine sediment organic matter composition in shallow photic sediments, Biogeosciences, 10, 5571-5588, doi:10.5194/bg-10-5571-2013, 2013.

Hemminga, M. and Mateo, M. A.: Stable carbon isotopes in seagrasses: Variability in ratios and use in ecological studies, Mar. Ecol.-Prog. Ser., 140, 285-298, 1996.

Hill, R., Bellgrove, A., Macreadie, P. I., Petrou, K., Beardall, J., Steven, A., and Ralph, P. J.: Can macroalgae contribute to blue carbon? An Australian perspective, Limnol. Oceanogr., 60, 1689-1706, 2015.

Ince, R., Hyndes, G. A., Lavery, P. S., and Vanderklift, M. A.: Marine macrophytes directly enhance abundances of sandy beach fauna through provision of food and habitat, Estuar. Coast. Shelf Sci., 74, 77-86, 2007.

Ikawa, H. and Oechel, W. C.: Temporal variations in air-sea $\mathrm{CO}_{2}$ exchange near large kelp beds near San Diego, California, J. Geophys. Res.-Oceans, 120, 50-63, 2015.

Kennedy, H., Beggins, J., Duarte, C. M., Fourqurean, J. W., Holmer, M., Marbà, N., and Middelburg, J. J.: Seagrass sediments as a global carbon sink: Isotopic constraints, Global Biogeochem. Cy., 24, GB4026, doi:10.1029/2010GB003848, 2010.

Koch, M. S. and Snedaker, S. C.: Factors influencing Rhizophora mangle L. seedling development in Everglades carbonate soils, Aquat. Bot., 59, 87-98, 1997.

Krause-Jensen, D. and Duarte, C. M.: Expansion of vegetated coastal ecosystems in the future Arctic, Front. Mar. Sci., doi:10.3389/fmars.2014.00077, 2014.

Krause-Jensen, D. and Duarte, C. M.: Substantial role of macroalgae in marine carbon sequestration, Nat. Geosci., 9, 737-742, doi:10.1038/NGEO2790, 2016.

Lucas, C., Thangaradjou, T., and Papenbrock, J.: Development of a DNA barcoding system for seagrasses: successful but not simple, PLoS ONE, 7, e29987, doi:10.1371/journal.pone.0029987, 2012.

Mateo, M. A., Sánchez-Lizaso, J. L., and Romero, J.: Posidonia oceanica 'banquettes': a preliminary assessment of the relevance for meadow carbon and nutrients budget, Estuar. Coast. Shelf. Sci., 56, 85-90, 2003.

Mayer, L. M.: Surface area control of organic carbon accumulation in continental shelf sediments, Geochim. Cosmochim. Ac., 58, 1271-1284, 1994.

Mazarrasa, I., Marbà, N., Lovelock, C. E., Serrano, O., Lavery, P. S., Fourqurean, J. W., Kennedy, H., Mateo, M. A., Krause-Jensen, D., Steven, A. D. L., and Duarte, C. M.: Seagrass meadows as a globally significant carbonate reservoir, Biogeosciences, 12, 4993-5003, doi:10.5194/bg-12-4993-2015, 2015.

McLeod, E., Chmura, G. L., Bouillon, S., Salm, R., Björk, M., Duarte, C. M., Lovelock, C. E., Schlesinger, W. H., and Silliman, B. R.: A blueprint for blue carbon: toward an improved understanding of the role of vegetated coastal habitats in sequestering $\mathrm{CO}_{2}$, Front. Ecol. Environ., 9, 552-560, 2011.

Mellbrand, K., Lavery, P. S., Hyndes, G., and Hambäck, P. A.: Linking land and sea: different pathways for marine subsidies, Ecosystems, 14, 732-744, 2011.
Milliman, J. D. and Droxler, A. W.: Neritic and pelagic carbonate sedimentation in the marine environment: ignorance is not bliss, Geol. Rundsch., 85, 496-504, 1996.

Moore, D. R.: Turtle grass in the deep sea, Science, 139, 1234 1235, 1963.

Moy, F. E. and Christie, H.: Large-scale shift from sugar kelp (Saccharina latissima) to ephemeral algae along the south and west coast of Norway, Mar. Biol. Res., 8, 309e321, doi:10.1080/17451000.2011.637561, 2012.

Nature Editorial: Blue Future, Nature, 529, 255-256, 2016.

Nellemann, C., Corcoran, E., Duarte, C. M., Valdes, L., DeYoung, C., Fonseca, L., and Grimsditch, G.: Blue Carbon, The role of healthy oceans in binding carbon, A Rapid Response Assessment, United Nations Environment Programme, GRID-Arendal, 80 pp., 2009.

Nguyen, X.-V., Höfler, S., Glasenapp, Y., Thangaradjou, T., Lucas, C., and Papenbrock, J.: New insights into DNA barcoding of seagrasses, Syst. Biodivers., 13, 496-508, 2015.

Ochieng, C. A. and Erftemeijer, P. L.: Accumulation of seagrass beach cast along the Kenyan coast: a quantitative assessment, Aquat. Bot., 65, 221-238, 1999.

Pendleton, L., Donato, D. C., Murray, B. C., Crooks, S., Jenkins, W. A., Sifleet, S., Craft, C., Fourqurean, J. W., Kauffman, J. B., Marbà, N., and Megonigal, P.: Estimating global "blue carbon" emissions from conversion and degradation of vegetated coastal ecosystems, PloS one, 7, e43542, doi:10.1371/journal.pone.0043542, 2012.

Polis, G. A. and Hurd, S. D.: Linking marine and terrestrial food webs: allochthonous input from the ocean supports high secondary productivity on small islands and coastal land communities, Am. Nat., 147, 396-423, 1996.

Poloczanska, E. S., Brown, C. J., Sydeman, W. J., Kiessling, W., Schoeman, D. S., Moore, P. J., Brander, K., Bruno, J. F., Buckley, L., Burrows, M. T., Duarte, C. M., Halpern, B. S., Holding, J., Kappel, C. V., O’Connor, M. I., Pandolfi, J. M., Parmesan, C., Schwing, F., Thompson, S. A., and Richardson, A. J.: Global imprint of climate change on marine life, Nature Climate Change, 3, 919-925, 2013.

Quisthoudt, K., Schmitz, N., Randin, C. F., Dahdouh-Guebas, F., Robert, E. M., and Koedam, N.: Temperature variation among mangrove latitudinal range limits worldwide, Trees, 26, 19191931, 2012.

Simeone, S. and De Falco, G.: Morphology and composition of beach-cast Posidonia oceanica litter on beaches with different exposures, Geomorphology, 151, 224-233, 2012.

Smith, S. V.: Marine macrophytes as a global carbon sink, Science, 211, 838-840, 1981.

Smith, S. V.: Parsing the oceanic calcium carbonate cycle: a net atmospheric carbon dioxide source, or a sink?, L\&O e-Books, Association for the Sciences of Limnology and Oceanography (ASLO), Waco, TX, doi:10.4319/svsmith.2013.978-0-98455912-1, 2013.

Tanaka, K., Taino, S., Haraguchi, H., Prendergast, G., and Hiraoka, M.: Warming off southwestern Japan linked to distributional shifts of subtidal canopy-forming seaweeds, Ecol. Evol., 2, 2854e2865, doi:10.1002/ece3.391, 2012.

Tokoro, T., Hosokawa, S., Miyoshi, E., Tada, K., Watanabe, K., Montani, S., Kayanne, H., and Kuwae, T.: Net uptake of at- 
mospheric $\mathrm{CO}_{2}$ by coastal submerged aquatic vegetation, Glob. Change Biol., 20, 1873-1884, 2014.

Unsworth, R. K., Collier, C. J., Henderson, G. M., and McKenzie, L. J.: Tropical seagrass meadows modify seawater carbon chemistry: implications for coral reefs impacted by ocean acidification, Environ. Res. Lett., 7, 024026, doi:10.1088/17489326/7/2/024026, 2012.

Valiela, I.: Marine Ecological Processes, Third Edn., Springer, New York, 698 pp., 2015.

Voerman, S. E., Llera, E., and Rico, J. M.: Climate driven changes in subtidal kelp forest communities in NW Spain, Mar. Environ. Res., 90, 119-127, 2013.

Waycott, M., Duarte, C. M., Carruthers, T. J., Orth, R. J., Dennison, W. C., Olyarnik, S., Calladine, A., Fourqurean, J. W., Heck, K. L., Hughes, A. R., and Kendrick, G. A.: Accelerating loss of seagrasses across the globe threatens coastal ecosystems, P. Natl. Acad. Sci. USA, 106, 12377-12381, 2009.
Wernberg, T., Thomsen, M. S., Tuya, F., Kendrick, G. A., Staehr, P. A., and Toohey, B. D.: Decreasing resilience of kelp beds along a latitudinal temperature gradient: potential implications for a warmer future, Ecol. Lett., 13, 685e694, doi:10.1111/j.14610248.2010.01466.x, 2010.

Whittaker, R. H. and Likens, G. E.: Carbon and the biota, Brookhaven Symp. Biol., 24, 281-302, 1973.

Wolff, T.: Utilization of seagrass in the deep sea, Aquat. Bot., 2, 161-174, 1976.

Woodwell, G. M., Rich, P. H., and Mall, C. S. A.: Carbon in estuaries, in: Carbon in the biosphere, edited by: Woodwell, G. M. and Pecari, E. V., US AEC, 221-240, 1973.

Ye, N.-H., Zhang, X.-W., Mao, Y.-Z., Liang, C. W., Xu, D., Zou, J., Zhuang, Z. M., and Wang, Q. Y.: Green tides' are overwhelming the coastline of our blue planet: taking the world's largest example, Ecol. Res., 26, 477-485, 2011. 